\title{
IMPROVING THE ABILITY OF MATHEMATIC STUDY PROBLEMS AND DISPOSITIONS SMP STUDENTS THROUGH IMPROVE METHOD
}

\author{
Rijaya $^{1}$, Utari Sumarmo ${ }^{2}$, Rudy Kurnia wan ${ }^{3}$ \\ ${ }^{1}$ SMP Negeri 1 Depok, Cirebon \\ ${ }^{2}$ IKIP Siliwangi, Bandung \\ ${ }^{3}$ IKIP Siliwangi, Bandung \\ 1ay.rijayar@yahoo.com, ${ }^{2}$ utari.sumarmo@gmail.com, ${ }^{3}$ krudy41@ yahoo.com
}

Received: March, 2018; Accepted: March, 2018

\begin{abstract}
This study aims to: 1) know the achievement of problem solving abilities and mathematical disposition of students, 2) the interaction between the learning model and the level of students' abilities to the achievement of problem solving abilities and mathematical dispositions and 3) the association of problem ability and mathematical disposition students. This research uses quantitative approach with experiment method. The instrument used is a type of description test. Data analysis was done quantitatively by using t-test and two-track ANOVA test. The result of this research concludes that the achievement of problem solving ability and mathematical disposition of students who gain learning with method Improve is better than students who get conventional learning either reviewed based on the whole students and based on students' early math ability. There is no interaction between learning method factors and the level of students' early mathematical ability toward the achievement of mathematical problem solving abilities. There is no interaction between the learning method and the students' early mathematical ability towards achieving mathematical disposition abilities. Students have a positive attitude towards the learning of mathematics and Improve Method.
\end{abstract}

Keywords: Problem Solving Ability, Mathematical Disposition, Improve Method

\begin{abstract}
Abstrak
Penelitian ini bertujuan untuk: 1) mengetahui pencapaian kemampuan pemecahan masalah dan disposisi matematik siswa, 2) interaksi antara model pembelajaran dan level kemampuan siswa terhadap pencapaian kemampuan pemecahan masalah dan disposisi matematik dan 3) asosiasi kemampuan masalah dan disposisi matematik siswa. Penelitian ini menggunakan pendekatan kuantitatif dengan metode eksperimen. Instrumen yang digunakan adalah jenis tes uraian. Analisis data dilakukan secara kuantitatif dengan menggunakan uji-t dan uji ANOVA dua jalur. Hasil penelitian menyimpulkan bahwa pencapaian kemampuan pemecahan masalah dan disposisi matematik siswa yang memperoleh pembelajaran dengan metode Improve lebih baik daripada siswa yang memperoleh pembelajaran konvensional baik ditinjau berdasarkan keseluruhan siswa maupun berdasarkan kemampuan awal matematik siswa. Tidak terdapat interaksi antara faktor metode pembelajaran dan level kemampuan awal matematik siswa terhadap pencapaian kemampuan pemecahan masalah matematik. Tidak terdapat interaksi antara metode pembelajaran dan kemampuan awal matematik siswa terhadap pencapaian kemampuan disposisi matematik. Siswa memiliki sikap positif terhadap pembelajaran matematika dan Metode Improve.
\end{abstract}

Kata Kunci: Kemampuan Pemecahan Masalah Matematik, Disposisi Matematik, Metode Improve. 
How to Cite: Rijaya., Sumarmo, U., Kurniawan, R. (2018). Improving The Ability of Mathematics Study Problems and Dispositions SMP Students through Improve Methode. JIML, 1 (1), 34-43.

\section{INTRODUCTION}

The curriculum is designed so that students have the attitude, knowledge, and skill competencies so that they can be productive, critical, creative, and innovative individuals and citizens. Problem solving abilities and dispositions mathematical are essential affective skills and behaviors that need to be possessed by and developed in Junior High School students in the achievement of the curriculum. This is as contained in the 2013 curriculum (BSNP: 2013) that the objectives of mathematics learning include: 1) solving problems that include the ability to understand problems, designing mathematical models, solving models and interpreting solutions obtained, 2) having an appreciative attitude to the use of mathematics in life, curiosity, attention and interest in learning mathematics, as well as a tenacious attitude and confidence in problem solving. Item 1) in the mathematics learning objective above describes the ability of mathematical thinking, while point 2) describes the affective domain that must be possessed by students in learning mathematics.

The ability of mathematical thinking that students need to master is solving mathematical problems. The ability to solve mathematical problems needs to be developed, NCTM (2000) argues that problem solving is the process of applying previously acquired knowledge to new and different situations. In addition NCTM also emphasizes the importance of problem solving, because problem solving is an integral part of mathematics learning so it should not be released in mathematics learning. Problem-solving abilities are not only needed to solve problems in mathematics, but also students need to solve problems they experience in everyday life.

The term problem solving according to Sumarmo (2012) has two meanings as a learning approach and as a mathematical ability. As a learning approach, problem solving is an approach that presents contextual problems as a starting point and then gradually reinvents and understands mathematical material / concepts / principles. As a learning goal or ability to be achieved after learning, problem solving is an activity in which the solution of a problem is not known or not immediately discovered. In solving the problem students must integrate their knowledge by developing a new understanding.

On the other hand, according to Sumarmo (2012) that mathematics education has a role in developing reasoning ability, systematic thinking, critical and careful, foster self-confidence, and develop an objective and open attitude that is indispensable in the face of an everchanging future. Attitudes and habits of such thinking are cumulatively cultivate mathematical disposition (Mathematical Disposition) is a desire, awareness, and a strong dedication to students to learn mathematics and perform various mathematical activities.

In a broader sense the mathematical disposition is not just an attitude but also as a tendency to think and act positively. With the development of mathematical disposition in the students will have a positive impact on the learning activities of mathematics, where learners will be more appreciative of the learning process until finally get the results of mathematics learning activities that have been done. 
36 Rijaya, Sumarmo, U., \& Kurniawan, R. (2018). Increase Problem Solving Ability and Mathematics Student Disposition of Junior High School Through Improve Method.

So it can be concluded, that the mathematical disposition is a reflection of students' positive appreciation of mathematics. Disposition is an affective specification, including a genuine interest in mathematical concepts and mathematical problem solving, persistence in finding solutions to problems, willingness to find processes or solutions to the same problem, and appreciating mathematical relationships with other disciplines.

The above description shows that high level ability in mathematics such as mathematical problem solving is still far from expected in the curriculum 2013. Based on the observations that researchers do in one of the junior high, the fact in the field in implementing mathematics learning obtained information that learning mathematics done in schools can fully develop students' high-level mathematical abilities such as mathematical problem-solving abilities. Mathematics learning is generally still going on traditionally with teacher-centered characteristics, using conventional learning so that the teacher more dominates the process of learning activities in the classroom while passive students, in addition to the exercises given more questions that are routine, students are trained to solve the problem without being seen the process mathematical problem solving so that less train the reasoning power in problem solving and thinking ability of students only at low level. As an example of many students who have difficulty when completing the national exam questions, especially mathematics and mathematics applications. Not a few students who see mathematics as a difficult subject and boring.

To change the students' view of mathematics learning requires an effort to improve the situation. As an effort to facilitate students, teachers need to make improvements in learning to change the situation. One of efforts that can be done is to improve the factors that enable influence student learning outcomes, including learning strategy factors. A suitable and appropriate learning strategy in mathematics lessons is a crucial part of achieving learning goals, as well as overall educational goals. These improvements are certainly expected to be effective in improving the ability to solve mathematical problems, it is necessary to have a special learning strategy to help students to more easily in the learning process. For that, should be needed a method of learning that can improve the quality of learning and invite students to be more active and creative in learning. Various learning methods that make students play an active role in learning one of them is method Improve.

Based on the above description, the authors propose method Improve as a solution. What is meant by the method Improve is one method that has three interdependent components namely first,activities metacognitive and practicing problem solving is required to read and interpret meanings and problems. Second, interaction with peers where students are required to communicate and explain their thoughts on mathematical ideas, using mathematical language to present ideas that describe relationships and modeling, and third, systematic activities of feedback, improvement and enrichment. The advantages of learning by using this method Improve is that students will be actively involved in learning because with group learning to make students freely to express their ideas, students will be eager to do the problems related to daily life and metacognitive questions are also answered students really really.

Several studies have reported advantages of the method Improve rather than conventional learning in developing: the ability of mathematics learning outcomes of high school students (Laksono, 2014), and students' critical thinking skills (Mujib, 2016), problem solving and mathematical communication of vocational students (Septiani, 2016). 
Another factor that is thought to be strong enough to influence mathematics learning outcomes is the students' early ability to study math. According to Suparman (in Razak, 2017) suggests that "early skills are the knowledge and skills students already possess so they can follow the lessons well. Meanwhile, according to Winkel (in Razak, 2017) suggests that "early ability is a bridge to get to the final ability. Each learning process has its own starting point or stems from the initial ability of certain students to be developed into new abilities, any what is the goal in the learning process. With this ability students can learn the material to be taught teacher and vice versa without this ability students will have difficulty learning the next material. At the beginning of the teaching and learning process, teachers should first examine students' early skills. From this initial ability depends on how the learning process should be arranged so that the expected learning outcomes are achieved.

Based on the above description the authors are interested to create a paper entitled "Improving Problem Solving Ability and Mathematical Disposition of Junior High School Students Through Method Improve"

As implicit in the title and based on the background of problems that have been stated previously. So that becomes the problem formulation in this research Is the achievement of mathematical problem solving skills of junior high school students whose learning using method Improve is better than using ordinary learning in terms of student KAM ?, Is the mathematical disposition of junior high school students whose learning using method Improve is better than using ordinary learning in terms of student KAM ?, Is there is an interaction between learning and the level of early ability of mathematics students with the achievement of mathematical problem solving skills and the achievement of mathematical disposition of students? and Is there an association between Problem solving abilities and mathematical disposition of junior high school students in both classes using method Improve and in class using conventional learning?

\section{METHOD}

The research method used in this research is quasi experimental research method because the sampling is not done random subjects, but using the existing subject in the field to be given special treatment. Special treatment in the form of learning by using method is Improve given in the experimental class, while the control class is given the usual treatment or method expository. Before and after the research was given a good test on the control class as well as the experimental class with each sample taken one class. The subjects of this study were 71 students of class VIII from one SMP determined purposively.

Based on the above description, the research design according to Ruseffendi (2005: 3) is as follows:

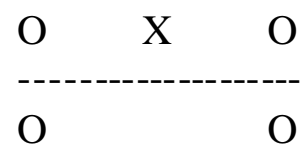

Description:

$\mathrm{O} \quad=$ initial test $=$ final test for communication skills and mathematical problem solving

$\mathrm{X} \quad=$ Learning using learning method Improve

------ = selection of sample not random subjects

Instruments in this study only use the test instrument, which is a test description to measure the ability of problem solving mathematics and students' mathematical communication skills. 
38 Rijaya, Sumarmo, U., \& Kurniawan, R. (2018). Increase Problem Solving Ability and Mathematics Student Disposition of Junior High School Through Improve Method.

For data analysis the researcher uses the help of program IBM SPSS software Statistics 24.0 and Microsoft Excel 2007.

\section{RESULTS AND DISCUSSION}

The following findings of the problem solving and mathematical disposition of students as shown in Table 1. After the normality test the distribution of data problem solving abilities and mathematical disposition obtained that the data is not normally distributed. Therefore, testing the difference in mean ability of problem solving and mathematical disposition is done by using Mann Whitney test.

Table 1.

Communication Skills and Mathematical Problem Solving Based on KAM

\begin{tabular}{|c|c|c|c|c|c|c|c|c|c|c|}
\hline \multirow{2}{*}{$\begin{array}{l}\text { Mathematical } \\
\text { Capabilities }\end{array}$} & \multirow{2}{*}{ KAM } & \multicolumn{3}{|c|}{ Improve Method } & \multicolumn{3}{|c|}{ Conventional } & \multicolumn{3}{|l|}{ Total } \\
\hline & & Mean & SD & $\mathbf{N}$ & Mean & SD & $\mathbf{N}$ & Mean & SD & $\mathbf{N}$ \\
\hline Mathematical & Height & 42.43 & 5.35 & 7 & 36.83 & 0.98 & 6 & 35.62 & 9.87 & 13 \\
\hline Problem & Medium & 36.39 & 4.49 & 18 & 27.62 & 7.81 & 21 & 31.36 & 8.42 & 39 \\
\hline \multirow{2}{*}{$\begin{array}{l}\text { Solving } \\
\text { (PMM) }\end{array}$} & Low & 27.91 & 7.01 & 11 & 25.00 & 6.16 & 8 & 26.47 & 6.76 & 19 \\
\hline & Total & 34.97 & 7.52 & 36 & 28.60 & 7.71 & 35 & 30.83 & 8.74 & 71 \\
\hline \multirow{4}{*}{$\begin{array}{l}\text { Mathematical } \\
\text { Disposition } \\
\text { (DM) }\end{array}$} & Height & 100.71 & 4.23 & 7 & 99.83 & 4.54 & 6 & 100.31 & 4.21 & 13 \\
\hline & Medium & 88.11 & 6.61 & 18 & 85.00 & 9.74 & 21 & 86.44 & 8.48 & 39 \\
\hline & Low & 81.00 & 8.97 & 11 & 71.63 & 7.86 & 8 & 77.05 & 9.55 & 19 \\
\hline & Total & 88.39 & 9.74 & 36 & 84.49 & 12.33 & 35 & 86.23 & 11.09 & 71 \\
\hline
\end{tabular}

Note: PMM ideal score: $50 \quad$ DM ideal score: 120

1. Mathematical problem Solving ability

From Table 1 shows that the overall student's mathematical problem-solving ability in a class using method Improve is higher than conventional class. While based on KAM, the higher KAM students the higher the value of their mathematical problem solving ability in the class using the method Improve, as well as in the class that uses conventional learning. The findings show that early mathematical skills take a good role in achieving students' mathematical problem-solving abilities. Likewise in each KAM, shows the value of the problem solving ability of mathematic students who learn by using the method Improve is higher than the value of problem solving ability of mathematic students who learn to use conventional learning. The findings show that method Improve has a good influence compared with conventional learning in achieving students' mathematical problem solving abilities.

Because KAM and Improve methods both have a good role in improving the achievement of mathematical problem-solving skills, which of them has a strong role. In Table 1 shows that the value of problem solving abilities in low-class KAMs using method Improve equals the value of problem-solving abilities in KAM being a class that uses conventional learning. Like wise the value of problem-solving abilities in KAM is a class that uses themethod Improve equal to the value-solving abilities in high-class KAM using conventional learning. The findings indicate that the method Improve has a larger role than the student KAM. 
While based on the results of statistical data processing in Table 1 above, the result of data analysis of experimental class postes using method Improve and control class with conventional learning using Sapiro-Wilk test which shows significant value of experiment class more than significant that used then $\mathrm{H}_{\mathrm{o}}$ accepted which means the sample comes from a normally distributed population. Unlike the case with the control class showed significantly less significant value used then $\mathrm{H}_{\mathrm{o}}$ rejected which means the sample comes from a population that is not normally distributed. Since the experimental class came from a normally distributed population and the control class came from a non-normally distributed population, no homogeneity test of variance was performed but a two-averaging test using the test was performed Mann-Whitney. Because the significant value is less than equal to the significance used from the test Mann-Whitney, $\mathrm{H}_{\mathrm{o}}$ is rejected, which means the achievement of mathematical problem solving ability of junior high school students whose learning using method Improve is better than conventional learning.

Based on data and facts contained above shows that the ability to solve mathematical problems can be increased by using themethod Improve. This is in line with research conducted Septiani (2016) which concludes that the problem solving ability of mathematics students who obtain learning by using method Improve is better than those who obtained conventional learning.

The findings of this study are similar to the findings of other studies (Husna, 2013, Juanda, 2014, Setiawan, 2015) that report students' experimental mathematical problem solving abilities better than conventional class students.

\section{Mathematical Disposition}

From Table 1 shows that the overall mathematical disposition of students in the class using the method Improve is higher than the conventional class, but not much different. While based on KAM, the higher KAM students the higher the value of mathematical disposition in the class using the method Improve, as well as in the classroom that uses conventional learning. The findings indicate that early mathematical skills take a good role in achieving student mathematical disposition. Likewise in each KAM, shows the value of mathematical disposition of students who learn by using method Improve is higher than the value of mathematical disposition of students who learn to use conventional learning. The findings show that method Improve has a good influence compared with conventional learning in achieving student mathematical disposition.

Because KAM and methods Improve both have a good role in improving the achievement of mathematical disposition, which of them has a greater role. We see from Table 1 shows that the value of problem solving skills in low-class KAMs using Improve method is lower than the mathematical disposition value in KAM being a class using conventional learning. The findings indicate that KAM students have a greater role than the method of learning.

After the learning process is done then given the scale of mathematical disposition to determine the mathematical disposition in the experimental class and control class. Based on manually data processing, the mathematical disposition scale data shows that the average of mathematical disposition of the experimental class and the control class are included in the high group. This illustrates that the experimental class whose learning using method Improve has no effect on the students' mathematical disposition.

Based on the results of statistical data processing resulted in data analysis of mathematical disposition of experimental class and control class by using test Shapiro-Wilk and Mann- 
40 Rijaya, Sumarmo, U., \& Kurniawan, R. (2018). Increase Problem Solving Ability and Mathematics Student Disposition of Junior High School Through Improve Method.

Whitney which showed significant value of experiment class more than significant used then $H_{o}$ accepted which means the sample comes from normally distributed population. Unlike the case with the control class significant value less than significant that is used then $H_{o}$ rejected which means the sample comes from the population that is not normally distributed it is not done homogeneity test variance but directly tested two averages using test Mann-Whitney. Because significant value is more than significant that used from test Mann-Whitney then $\mathrm{H}_{\mathrm{o}}$ accepted which means there is no difference of mathematical disposition level of junior high school students whose learning using method Improve with conventional learning.

The findings of this study are similar to the findings of another study by Bernard (2015) who found no difference in mathematical disposition of students in both learning. However, the findings of this study differ from studies (Permana, 2010, Qodariyah, 2015, Suharsono, 2015, Wulanmardhika, 2014) who reported mathematical dispositions of experiment class students better than conventional class students.
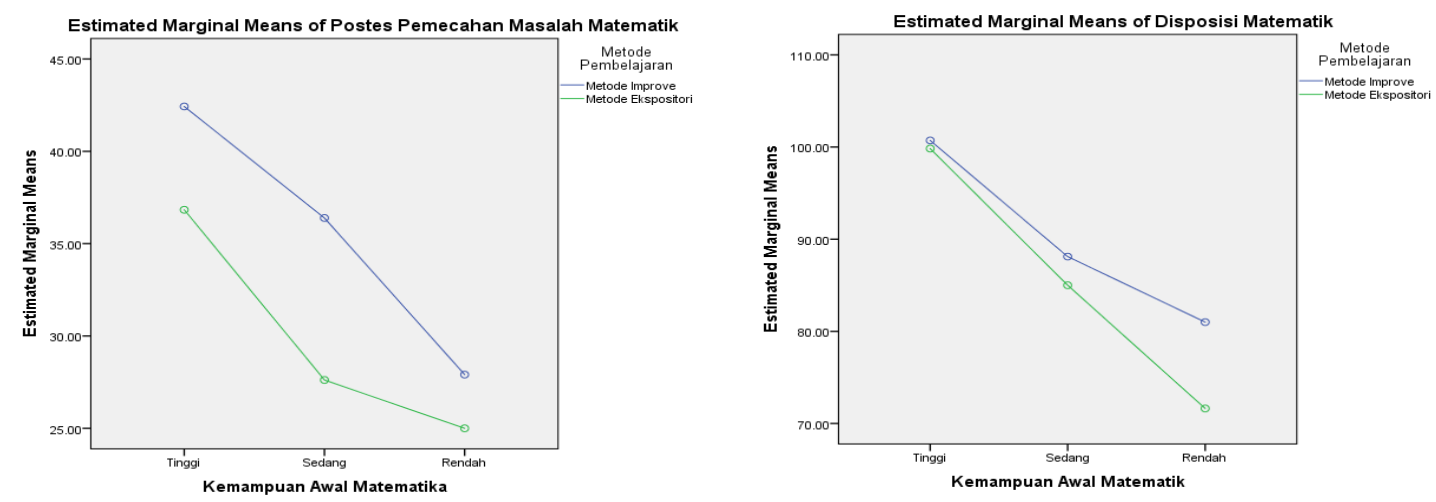

Figure 1. Interaction between KAM and Figure 2. Interaction between KAM and learning learning method in problem solving method in mathematical disposition ability of mathematic

The next analysis is done by using two-track Anova test. The results of the analysis found that there is no interaction between learning methods with KAM on the achievement of mathematical problem solving skills and there is no interaction between learning methods with KAM on achievement of mathematical disposition as shown in figure 1 and figure 2. Further research using Chi squared test in contingency table (table 3) found the contingency coefficient $\mathrm{C}=0.715$ and this means that there is an association between mathematical problem solving and mathematical disposition of students.

Table 3 Associations between Problem Solving Ability and Mathematical Disposition in Experimental Classes

\begin{tabular}{ll|r|r|r|r} 
& & \multicolumn{2}{c}{ Disposisi Matematik } & \multicolumn{1}{c}{} \\
& & Tinggi & Sedang & Rendah & Total \\
\hline $\begin{array}{l}\text { Kemampuan } \\
\text { Pemecahan Masalah } \\
\text { Matematik }\end{array}$ & Tinggi & 5 & 5 & 0 & 10 \\
\cline { 2 - 7 } & Sedang & 2 & 13 & 7 & 22 \\
\cline { 2 - 7 } & Rendah & 0 & 0 & 4 & 4 \\
\hline Total & 7 & 18 & 11 & 36 \\
\hline
\end{tabular}


Another advantage of learning by using metote Improve rather than conventional learning on the achievement of problem solving abilities and mathematical disposition, based on observations when learning by method Improve found the following circumstances. When learning by the method Improve was first introduced, students from KAM were low and were feeling confused because they always only accepted the teacher's explanation, but now they were able to describe the mathematical concepts in their own language, to create mathematical models, and to explain their ideas. Likewise students from high KAM can adapt to the site directly. In the following week, students at all levels can adapt to learning situations with methods Improve and their tasks, their fear of expressing opinions, to complete tasks, exercises accompanied by metacognition questions, reviewing, reducing difficulties, gaining knowledge and re-examining answers. These activities are seen in figures 3 and 4.

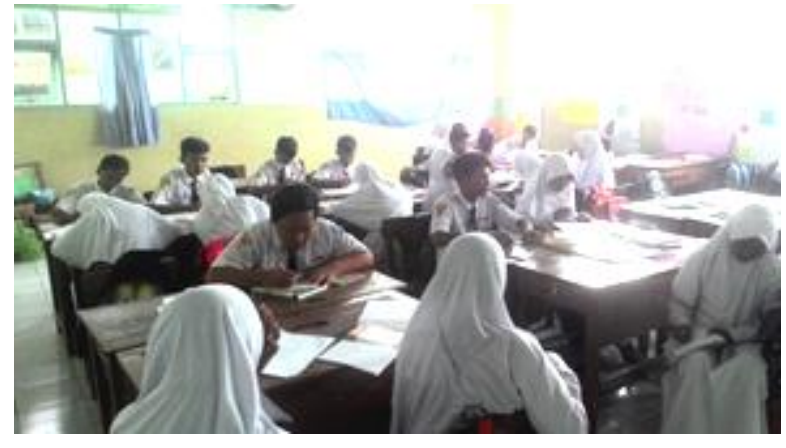

Figure 3. Learning activities

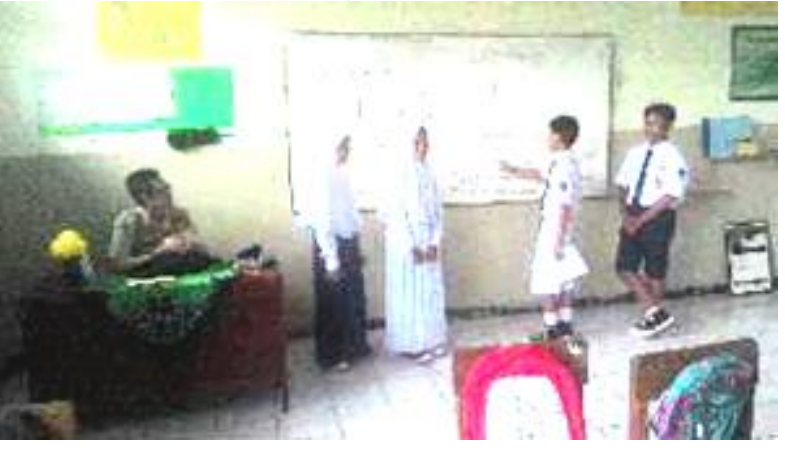

Figure 3. Presentation of discussion results

Although students in conventional learning have no difficulty following conventional learning, they experience little difficulty when they have to express their opinions, complete tasks, ask questions, explain, clarify, and review answer.

\section{CONCLUSION}

Based on the findings and discussion, the study describes several conclusions as follows: 1) The achievement of problem solving ability of mathematics learning using method Improve is better than conventional learning, 2) Mathematical disposition level of junior high school students whose learning using method is Improve same with conventional learning, 3 ) The learning of method Improve has better role compared to the early ability of mathematics in achieving problem solving ability and learning method does not give effect to the achievement of student's mathematical disposition, 4) No interaction between learning method with the ability of early mathematics in problem solving ability and mathematical disposition and 5) There is an association between problem-solving ability and mathematical disposition.

\section{REFERENCES}

BSNP. 2013. Standar Isi untuk Satuan Pendidikan Dasar dan Menengah, Standar Kompetensi dan Kompetensi dasar SMP/MTts. Pdf. Jakarta

Dahlan, Jarnawi A. 2011. Materi Pokok Analisis Kurikulum Matematika. Jakarta: Open University 
42 Rijaya, Sumarmo, U., \& Kurniawan, R. (2018). Increase Problem Solving Ability and Mathematics Student Disposition of Junior High School Through Improve Method.

Bernard, M. (2015). Meningkatkan Kemampuan Komunikasi dan Penalaran Serta Disposisi Matematik Siswa SMK dengan Pendekatan Kontekstual Melalui Game Adobe Flash Cs 4.0.. Thesis on Postgraduate STKIP Siliwangi. Unpublished.

Huda, Miftahul. 2013. Model-Model Pengajaran dan Pembelajaran. Yogyakarta: Student Literature.

Husna, 2013. Peningkatan Kemampuan Pemecahan Masalah Dan Komunikasi Matematis Siswa Sekolah Menengah Pertama Melalui Model Pembelajaran Kooperatif Tipe Think-Pair-Share (Tps). Journal of Opportunity, Volume 1, Number 2, April 2013, ISSN: 2302-5158

Juanda, M. 2014. Peningkatan Kemampuan Pemecahan Masalah dan Komunikasi Matematis Siswa SMP melalui Model Pembelajaran Means-ends Analysis (MeA.) Jurnal Kreano, Published by Mathematics Department FMIPA UNNES Volume 5 No. 2 December 2014

Laksono, RP 2014. Penerapan Pembelajaran Dengan Metode Improve Pada Materi Pertidaksamaan Di Kelas X-B Sman 1 Kauman Tulungagung. Mathedunesa Journal of Scientific Mathematics Education Volume 3 No 2 Year 2014

Mujib. 2016. Mengembangkan Kemampuan Berfikir Kritis Melalui Metode Pembelajaran Improve.: Journal of Mathematics Education Vol. 7, No. 1, 2016, pp 167 - 180

National Council of Teachers of Mathematics. 2000. Principles and Standards for School Mathematics. Reston, VA: NCTM

Permana, Y. 2010. Kemampuan Pemahaman dan Komunikasi serta Disposisi Matematik Eksperimen terhadap Siswa SMA melalui Model - Eliciting Activities. Dissertation at UPI Graduate School. Unpublished

Qodaryah, L. 2015 Meningkatkan Kemampuan Pemahaman Dan Komunikasi Serta Disposisi Matematik Siswa Smp Dengan menggunakan metode Discovery Learning. Thesis on Postgraduate STKIP Siliwangi Bandung. Unpublished.

Razak, F. 2017. Hubungan Kemampuan Awal Terhadap Kemampuan Berpikir Kritis Matematika Pada Siswa Kelas Vii Smp Pesantren Immim Putri Minasatene. Journal "Mosharafa", Volume 6, Number 1, January 2017, p-ISSN: 2086-4280; e-ISSN: 2527-8827. Published by Mathematics Education STKIP Andi Matappa.

Ruseffendi, E.T. (2005). Dasar-Dasar Penelitian Pendidikan dan Bidang non Eksakta Lainnya. Bandung:Tarsito

Septiani, H. 2016. Meningkatkan Kemampuan Pemecahan Masalah dan Komunikasi Matematik serta Disposisi Matematik Siswa SMK melalui Metode Improve. Thesis On Mathematics Education Study Program STKIP Siliwangi Bandung. Unpublished.

Setiawan, W. 2015. Meningkatkan Kemampuan Pemecahan Masalah dan Komunikasi Matematik serta Disposisi Matematik Siswa SMP melalui Pendekatan Pembelajaran Kontekstual.. Thesis On Mathematics Education Study Program STKIP Siliwangi Bandung. Unpublished.

Suharsono.2015. Meningkatkan Kemampuan Pemahaman Dan Disposisi Matematik Siswa Sma Menggunakanteknik Probing Prompting. Edusentris, Journal of Science and Teaching, Vol. 2 No. 3, December 2015

Sumarmo, U. 2012. "Pendidikan Karakter dan Pengembangan Kemampuan Berpikir dan Disposisi Matematik serta Pembelajarannya". Papers published in Suryadi, D., Turmudi, Nurlaelah, E. (Editor). Kumpulan Makalah Proses Berpikir dan Disposisi Matematik serta Pembelajarannya. 2015. pp.435-492. Bandung: Jurdik Matematika FPMIPA UPI.

Sumarmo, U. 2012. "Pendidikan Karakter dan Pengembangan Kemampuan Berpikir dan Disposisi Matematik serta Pembelajarannya". Papers published in Suryadi, D., 
Turmudi, Nurlaelah, E. (Editor). Kumpulan Makalah Proses Berpikir dan Disposisi Matematik serta Pembelajarannya. 2015. pp. 333-373. Bandung: Jurdik Matematika FPMIPA UPI.

Wulanmardhika, M. (2014). Meningkatkan Kemampuan Pemahaman, Penalaran, dan Disposisi Matematik Siswa SMA melalui Pembelajaran Generatif. Thesis on UPI Graduate, not published. 